\section{IJ§ER}

ISSN: 2149-5939
International Journal of Social Sciences and Education Research

Online, http://dergipark.gov.tr/ijsser

Volume: 3(4), 2017

\title{
Eliminating the misconceptions about image formation in plane mirrors by conceptual change texts
}

\author{
Süleyman Aydın ${ }^{1}$ \\ Received Date: 01 / 04 / 2017 \\ Accepted Date: 07 / 07 / 2017 \\ Abstract \\ By exploring the Science Teacher program students' misconceptions, this study was aimed to eliminate their \\ misconceptions about image formation in plane mirrors by conceptual change texts. The data were obtained \\ by applying a three-tired multiple choice test. The sample of the study were 90 sophomore students studying \\ in Agri Ibrahim Cecen University Faculty of Education, Science Education Department. The conceptual \\ change texts were then prepared to apply for instructional method in experimental group. By being parallel \\ to each other conceptual change text method for experimental group and traditional lecturing method for \\ control group were applied respectively. Later the multiple choice test were applied as post-test in both \\ experimental and control group. The study showed that the conceptual change texts were more effective than \\ traditional method for instruction to eliminate students' misconceptions about image formation in plane \\ mirrors. \\ Keywords: Science Education, Physics Education, Optics, Geometric Optics, Misconceptions, Conceptual \\ Change Texts.
}

\section{Introduction}

Physics education can be done well only with the application of new and effective teaching methods and techniques. The conceptual teaching is taking the most important place among these methods and techniques. Numerous studies have been conducted in the national and international literature to determine students' understanding of basic science concepts in recent years (Geban \& Bayır, 2000; Kaya \& Büyükkasap, 2004; Kaya \& Kavcar, 2002; Carmichael et al., 1990; Pfund \& Duit, 1991; Wandersee et al., 1994; Gilbert \& Watts, 1983; Helm, 1980; Novak, 1977; Driver \& Easly, 1978; Kaya, 2010; Demirbaş et al., 2011; Akyürek \& Afacan, 2013; Üce \& Sarıçayır, 2013; Sarı Ay \& Aydoğdu, 2015). One of the most important factors affecting concept learning is the preliminary knowledge that students have before teaching. Many studies in the literature show that students come from with a variety of prior knowledge and concepts related to scientific events that are different from those accepted by the scientific environments and this prior knowledge prevent students from learning scientific principles and concepts correctly (Griffiths \& Preston, 1992; Andersson, 1986). According to the constructivist learning theory, which is one of the most supported theory of learning in the last two decades, which has been put forth to explain how learning has taken place, the student makes new meaningful information by comparing it with the information he already has (Bodner, 1986). For this reason, students 'preliminary information and if they have, their misconceptions should be revealed seriously and teaching should be planned with taking these considerations in mind. Such preliminary information is generally less logical, less precise, less common, and resistant to teaching than accepted scientific theories students build on this preliminary knowledge of their newly acquired

\footnotetext{
${ }^{1}$ Agri Ibrahim Cecen University, Faculty of Education, Agri, Turkey, yupul@hotmail.com 
Aydın, S. (2017). Eliminating the misconceptions about image formation in plane mirrors by conceptual change

texts. International Journal of Social Sciences and Education Research, 3(4), 1394-1403.

knowledge. For this reason, if the preliminary information is erroneous, the information on them may be erroneous (Hewson \& Hewson, 1984). It is called conceptual change that these incorrect preliminary information that students have are replaced with correct information.

In order for the conceptual change to be realized:

- Students need to be aware of the inadequacy of their knowledge.

- Students need to understand the new knowledge given to them.

- It is necessary for the students to find new information given to them sensitive.

- Students need to use new knowledge given to them to solve new problems they have encountered (Posner et al., 1982).

The traditional method of concept teaching consists of steps such as giving the expression that expresses the concept to the student, making a verbal definition of the concept, specifying the descriptive and distinguishing qualities of the concept for the definition, and providing the student to find examples that are not included with the concept. This method is not effective enough to teach concepts; because in many concepts the distress is caused by the inability to make a definite verbal definition. Moreover, the traditional methods have other difficulties in terms of effective learning. To overcome these difficulties, it is necessary to know how the learning takes place so that a more effective learning can take place.

There are various learning theories that try to explain the ways in which the learners take place. Cognitive learning theory is the most accepted of these. Cognitive learning usually involves learning about concepts, principles, laws, theories, and the information related to the problemsolving process. In fact, there are three main parts in learning; cognitive, emotional and psychomotor skills. However, since there is a very close relationship between these three areas, it is difficult to distinguish them from each other with certain lines.

The misconceptions are rather personal experiences, results that are contrary to scientific facts and thoughts, that prevent learning meaningfully (Özkan et al., 2001). For this reason, one of the main goals of today's science education is to help the students to establish and eliminate the misconceptions that they have. Investigations are still carried out in this area (Bilgin \& Geban, 2001, Büyükkasap et al., 2001a, Ery1lmaz, 2002, Esiobu \& Soyibo, 1995, Fetherstonehaugh \& Treagust, 1992; Akyürek \&Afacan, 2013; Üce \& Sarıçayır, 2013; Sarı Ay \& Aydoğdu, 2015).

One of the most visible topics of science mistakes, especially in physics, is the concept of light. Concerning light, there are many researches that reveal many misconceptions. Findings from these studies related to the propagation of light, nature of light and reflection of light, have shown that students have conceptual misconceptions propagation of light, nature of light and reflection of light. In order to overcome this misconceptions, teachers must first try to determine the misconceptions, then they must concentrate on the misconceptions, offer new, logical and useful concepts, reinforce new concepts with experiential examples and even reorganize their curriculum programs taking into account their intuition and thoughts (Büyükkasap et al., 2001b, Büyükkasap \& Samanc1, 1998, Kaya \& Büyükkasap, 2004, Akdeniz et al., 2000; Brown, 1992; Cansüngü \& Bal, 2002; Carmichael et al., 1990).

It has been shown that in studies on correcting concept misconceptions, it is possible to eliminate the students' misconceptions in the related physics and science subjects by using conceptual change texts, activities, computer-based course presentations and analogies and these misconceptions can be eliminated more successfully than traditional teaching methods 
Aydın, S. (2017). Eliminating the misconceptions about image formation in plane mirrors by conceptual change texts. International Journal of Social Sciences and Education Research, 3(4), 1394-1403.

(Büyükkasap et al., 1998, Brown, 1992). It is known that students have preliminary information on various topics before entering the teaching process and that these preliminary information that students have are significantly different from the scientific information in the curriculum. Some of the main reasons for concept misconceptions are: wrong or incomplete perception of previously acquired concepts, that is, not conform to the scientific definition of the concept; have different functions in the scientific language of the concepts used in everyday language; that the establishment of appropriate learning environments while teaching subjects and concepts; that the appropriate learning environments are not established while the subjects and concepts are taught; that the concepts are presented without being linked to each other and often associated with everyday events.

The importance of concept teaching in the light of concept misconceptions is becoming more evident. "The nature, reflection and refraction of light", which is one of the main topics of science education starting from primary education, is the basic subjects in which students constantly struggle during their education. Hence, the better understanding of these basic subjects will be the benefit of the concept teaching. One of the most effective methods of concept teaching is the application of conceptual change texts and the conceptual change texts are likely to have a positive effect in the teaching of image formation in the plane mirror of geometric optics.

The purpose of this study is; to determine the science teacher candidates' misconceptions about image formations in plane mirrors and reflections, to prepare conceptual change texts from the findings, and to determine the effects of conceptual change texts on the elimination of misconceptions compared to traditional teaching methods.

\section{Method}

In the present study, quasi-experimental pretest-posttest control group research design was used as a quantitative research method in order to determine the effectiveness of conceptual change approach and the traditional method (Linn \& Gronlund, 2000, Fraenkel \& Wallen, 2003).

Preliminary test results were examined for assignment of experimental and control groups, and the experiment and control groups were specified randomly because there was no statistically significant difference between the two groups.

Table 1. The application of quasi-experimental design

\begin{tabular}{|l|l|l|l|}
\hline Groups & Pre-est & Application & Post-Test \\
\hline Experiment & $\mathrm{T}_{1}$ & Conceptual Change & $\mathrm{T}_{2}$ \\
\hline Control & $\mathrm{T}_{1}$ & Traditional Method & $\mathrm{T}_{2}$ \\
\hline
\end{tabular}

The application of the Semi-Experimental Design is summarized in Table 1. According to this table; the prepared test was first applied to both groups and then the lessons were processed according to the conceptual change approach in the experimental group while the lessons were traditionally processed in the control group and the same test was applied as a post-test of both groups. The sample of the study was composed of 92 science teacher candidates. 
Aydın, S. (2017). Eliminating the misconceptions about image formation in plane mirrors by conceptual change texts. International Journal of Social Sciences and Education Research, 3(4), 1394-1403.

\section{Findings}

\section{Interpretations for the first question}

At midnight, Ahmet is awakened by mosquito bites on his chin. He takes a flashlight and faces a mirror. In his darkened bedroom, if he wants to see his chin in the mirror very clearly, what should he aim the flashlight at?

(A) The flashlight should be aimed at the plane mirror.

(B) The flashlight should be aimed at his chin.

(C) The flashlight should be aligned parallel to the mirror.

(D) The direction in which the flashlight is aimed doesn't make any difference.

-(E)

(2) Which of the following ray diagrams can best explain your answer in (1)? (Chen et al., 2002).
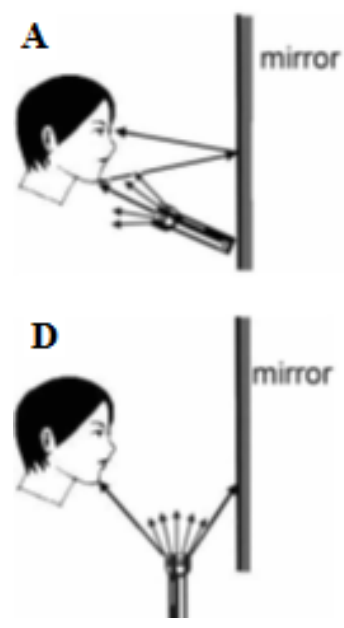

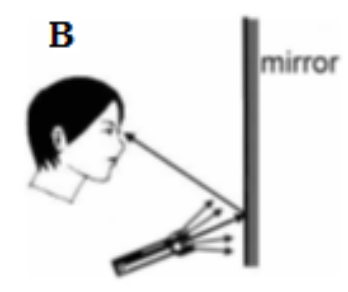

$\mathbf{E}$

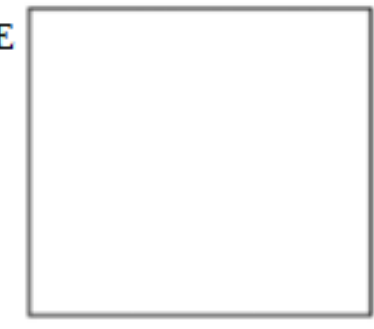

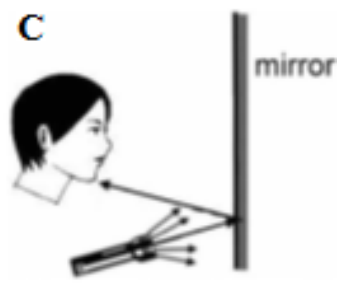

It was seen that the students continued their misconceptions "The mirror must be illuminated in order to be able to see an object in a dark room." by $28.6 \%$ in this question. This misconception decreased by $5.7 \%$ after the implementation of the conceptual change texts. The pupils continued the misconceptions "In order to see an object in a plane mirror in a dark room, both the mirror and the object have to be illuminated." of $11.4 \%$. This error decreased by $31.4 \%$ after the application of the conceptual change texts.

Interpretations for the second question

As shown in the figure, a plane mirror and a pencil are placed on top of a table. A boy and a girl sit side by side in front of the table, looking into the mirror. The relative locations of the pencil, mirror, boy and girl are shown on the right. 
Aydın, S. (2017). Eliminating the misconceptions about image formation in plane mirrors by conceptual change texts. International Journal of Social Sciences and Education Research, 3(4), 1394-1403.

(1) Which of the following statements is correct? (Please check)

(A) The locations of the image seen by both students are the same.

(B) The location of the image seen by the boy is on the right side of that seen

by the girl.

(C) The location of the image seen by the boy is on the left side of that seen

by the girl.

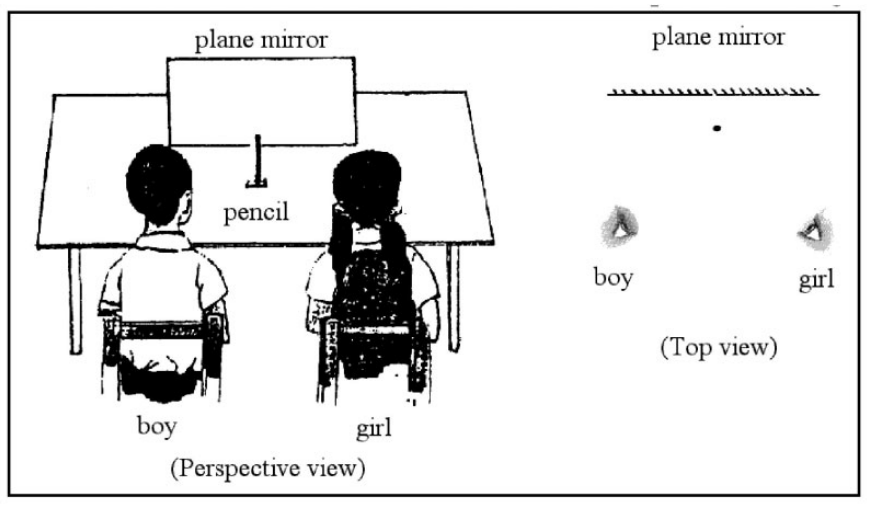

(D)

(2) Which of the following ray diagrams can best explain your answer? (Chen et al., 2002).

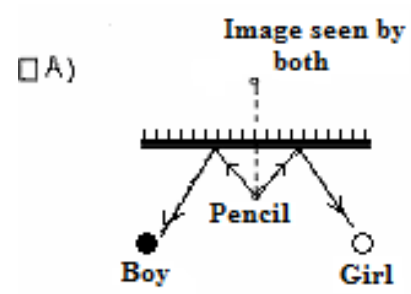

口C)

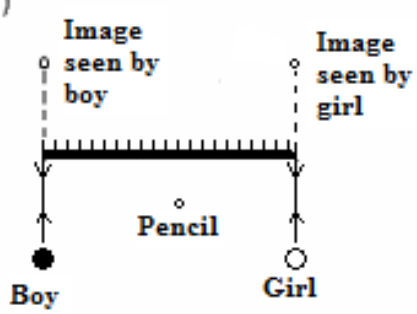

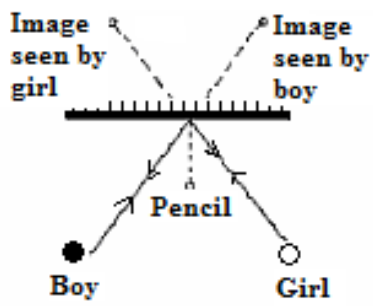

पD)

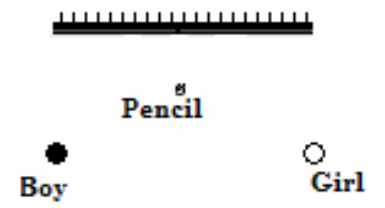

$37.1 \%$ of the students have the misconception of "The image of an object is in extension of the gaze direction of the observer." This misconception was decreased by $14.2 \%$ after the application of the conceptual change texts.

\section{Interpretations for the third question}

A plane mirror and a pencil are placed on a tabletop. An observer is looking into the mirror to observe the image of the pencil. The experiment is performed in a darkened room. A lamp is the only illuminant inside the room.

(1) If the lamp is raised a little higher, what will happen to the location of the image of the pencil seen by the observer? Please check.

(A) It will move up.

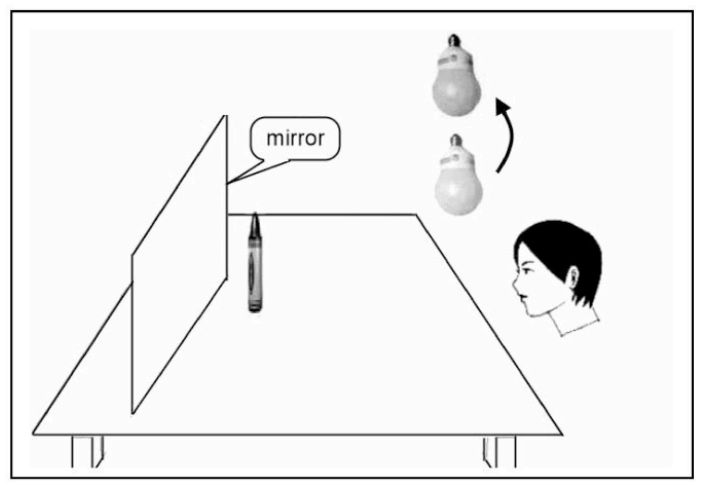

-(B) It will move down.

-(C) It will stay in the same place.

(D) 
Aydın, S. (2017). Eliminating the misconceptions about image formation in plane mirrors by conceptual change texts. International Journal of Social Sciences and Education Research, 3(4), 1394-1403.

(2) Which of the following ray diagrams can best explain your answer? (The dotted and solid lines indicate the light ray paths, before and after the lamp is raised.) (Chen et al., 2002).
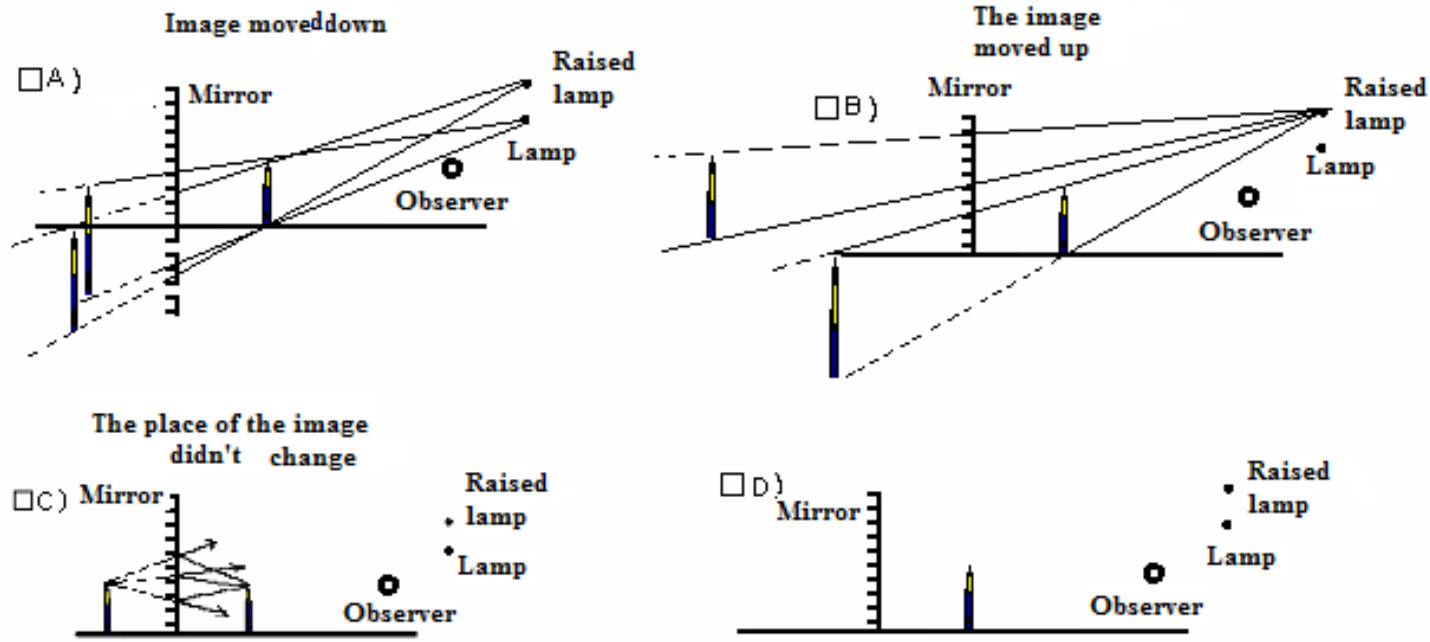

$8.6 \%$ of the students continued the carry the misconception "If the light source is raised higher than the position the image of the object also slides up." It was observed that $2.9 \%$ increase happened after the application of conceptual change texts. $25.7 \%$ of the students continued the carry the misconception "If the light source is raised higher than the position the image of the object slides down." But this misconception was decreased in the rate of 22.9 after the application of conceptual change texts.

Interpretations for the fourth question

If the observer moves a little farther from the mirror while the lamp stays fixed, what will happen to the location of the image of the pencil seen by the observer?

(1) Please check:

(A) It will retreat from the mirror.

-(B) It will approach the mirror.

(C) It will stay at the same location.

(D)

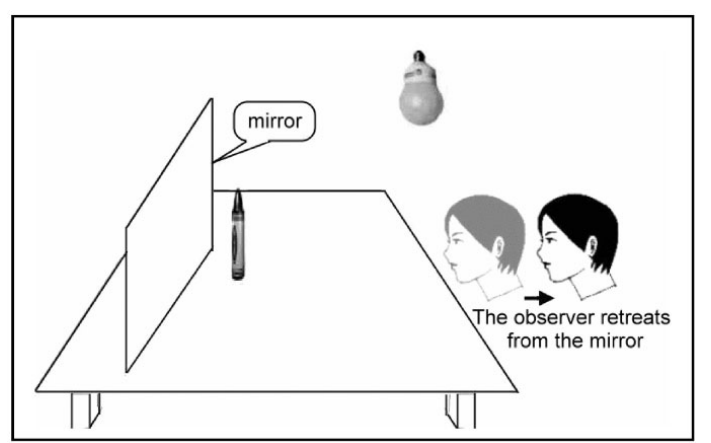

(2) Which of the following ray diagrams can best explain your answer? (The dotted and solid lines indicate the light ray paths, before and after the observer retreats from the mirror.) (Chen et al., 2002). 
Aydın, S. (2017). Eliminating the misconceptions about image formation in plane mirrors by conceptual change texts. International Journal of Social Sciences and Education Research, 3(4), 1394-1403.

$\square$ A)
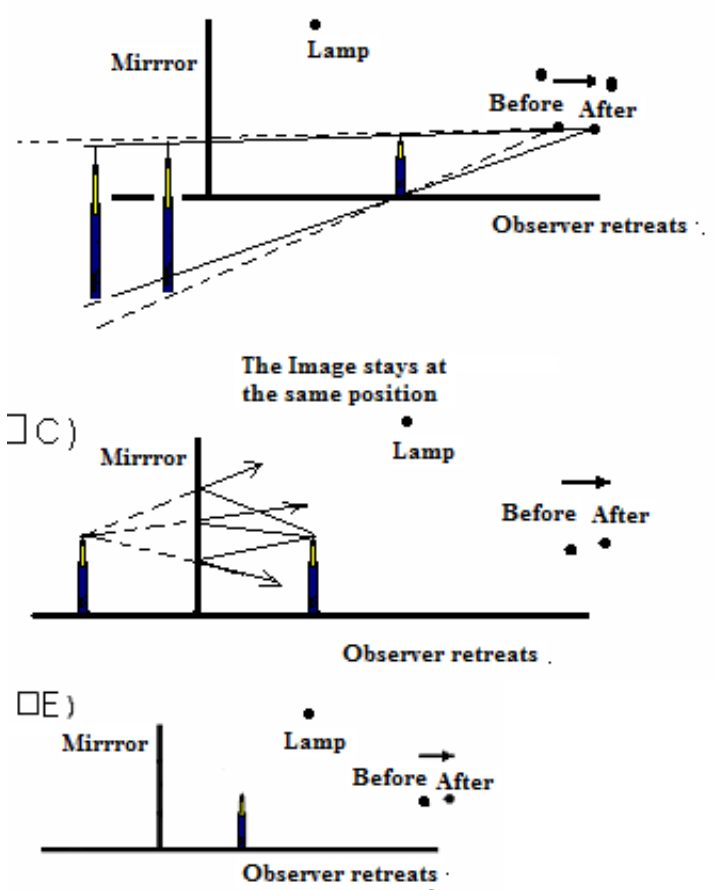
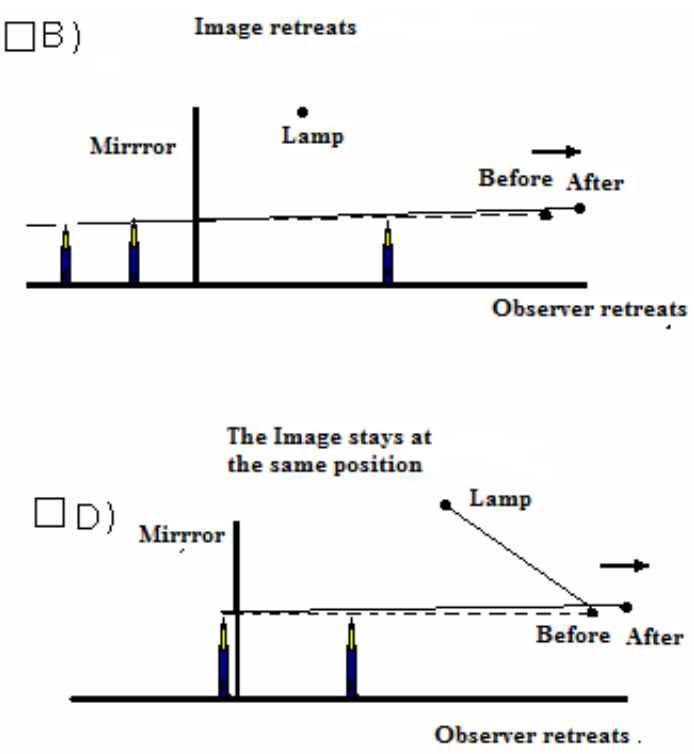

It is seen that $20.0 \%$ of the students have carried the misconception "If the observer is retreats from the mirror, the image will also retreat." $14.3 \%$ of the students gave up these misconception after applying the conceptual change texts. Of the students, $17.1 \%$ said, "If the observer retreats from the mirror, the image of the object will approaches the mirror". The students have these misconceptions at the same rate after the application of conceptual change texts.

\section{Interpretations for the fifth question}

(1) Which of the following statements is correct?

(A) The observer can see the black ball in the mirror.

(B) The observer can't see the black ball in the mirror.

(C)

(2) Which of the following statements can best explain your answer?

(A) The black ball scatters external light, some of which heads toward and reflects from the mirror.

_(B) The black ball emits light, some of which heads toward and reflects from the mirror.

(C) The black ball neither scatters nor emits light.

(D) The lines of vision from the observer reflect from the mirror and then impinge on the black ball.

-(E) 
Aydın, S. (2017). Eliminating the misconceptions about image formation in plane mirrors by conceptual change texts. International Journal of Social Sciences and Education Research, 3(4), 1394-1403.

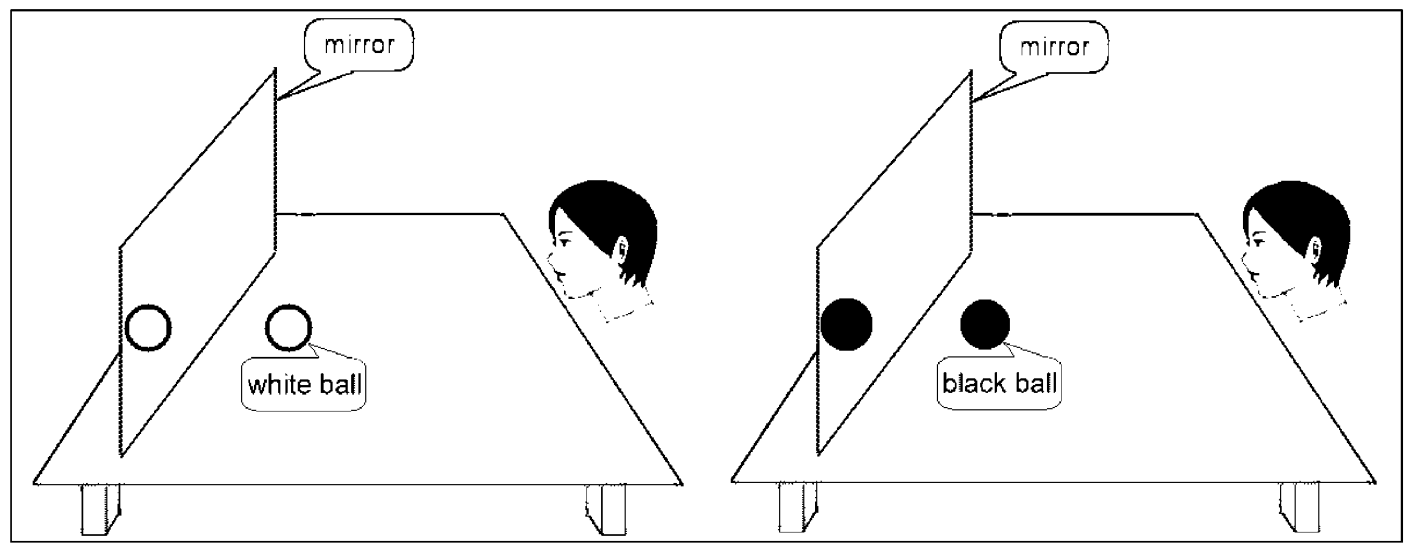

(Chen et al.,2002).

$74.3 \%$ of respondents answered that they could not see the image of black ball. As a reason for this misconception of the students thought; $14.3 \%$ black balls absorb the heat, $20.0 \%$ the black balls do not emit light and $42.9 \%$ the image lines come from the observer.

\section{Result and discussions}

According to the findings obtained from the post-test results, the level of comprehension of teacher candidates after the application of conceptual change texts has increased considerably. This increase was $14 \%$ in the experimental group and $5 \%$ in the control group. Students' understanding levels of reflection of light are low. Because at the understanding level students can organize and interpret what they learn that is, the student can visualize the information presented to him in his mind and express it in different forms and different phrases. (Özcan \& Oluk, 2007). When the answers given by the students are examined, especially in the second stage of the questions in the test, the students could not express the information they had learned in different sentences. In addition, students were inadequate in expressing the information required to be given in most of the questions. The major misconceptions of students on the reflection of light are; "In order to see an object in a plane mirror in a dark room, both the mirror and the object must be illuminated.", "The image that occurs in the plane mirror moves by moving the observer and its size changes." and "The image of the black ball can not be seen in the mirror. These results are parallel to the results of other researchers. (Chen et al., 2002). It is thought that it is important for teachers to emphasize the light source and show the observer in the picture while drawing drawings related to the image formation in order not to make such misconceptions that the students have had. In this study, in general, students' misconceptions about geometric optics can be reduced by $53 \%$ in total by applying conceptual change texts, but this change can only be realized at $34 \%$ in the control group where traditional teaching method is used.

The results shows that the lessons learned using conceptual change texts will be effective in understanding the concepts related to the subject. This results supported by the similar studies in which the effectiveness of the conceptual change texts is searched (Kaya, 2010, Demirbas et al., 2011, Akyürek \& Afacan, 2013, Üce \& Sarıçayır, 2013, Sarı Ay \& Aydogdu, 2015). Posner et al., (1982) suggests that science educators should consider the conceptual change process seriously and that conceptual change can be realized if the students be aware of the inadequacy of their knowledge, find new knowledge given her/him understandable and logical, and that students should use the new information given to her/him to solve the new problems (s)he has 
Aydın, S. (2017). Eliminating the misconceptions about image formation in plane mirrors by conceptual change texts. International Journal of Social Sciences and Education Research, 3(4), 1394-1403.

encountered. It has also been reported in several studies that the conceptual change texts are one of the effective teaching methods in solving the misconceptions that students have in science subjects (Pınarbaşı, 2002; Palmer, 2003; Chen et al., 2002).

\section{References}

Akdeniz, A. R., Yıldız, İ. \& Yiğit, N. (2001). İlköğretim 6. Sınıf Öğrencilerinin Işık Ünitesindeki Kavram Yanılgıları. Çukurova Üniversitesi Eğitim Fakültesi Dergisi, 2(20), $72-78$.

Akyürek, E. \& Afacan, Ö. (2013). İlköğretim 8. Sınıf Öğrencilerinin Hücre Bölünmesi ve Kalıtım Ünitesindeki Kavram Yanılgılarının Tespiti ve Anoloji ile Kavramsal Değişim Metinleri Kullanılarak Giderilmesi. Ahi Evran Üniversitesi Kırşehir Eğitim Fakültesi Dergisi, 14(1).

Andersson, B. (1986). Pupils' Explanations of Some Aspects Of Chemical Reactions. Science education, $70(5), 549-563$.

Bilgin, İ. \& Geban, Ö. (2001). Benzeşim (Analoji) Yöntemi Kullanarak Lise 2. Sınıf Öğrencilerinin Kimyasal Denge Konusundaki Kavram Yanılgılarının Giderilmesi. Hacettepe Üniversitesi Ĕgitim Fakültesi Dergisi, 20(20).

Bodner, G. M. (1986). Constructivism: A Theory of Knowledge. J. Chem. Educ, 63(10), 873.

Brown, D. E. (1992). Using Examples and Analogies to Remediate Misconceptions in Physics: Factors İnfluencing Conceptual Change. Journal of Research in Science Teaching, 29(1), 17-34.

Büyükkasap, E., Düzgün, B. \& Ertuğrul, M. (2001). Lise Öğrencilerinin Işık Hakkındaki Yanlış Kavramları. Milli Eğitim Dergisi, 149, 32-35.

Büyükkasap, E.\& Samanc1, O. (1998). İlköğretim Öğrencilerinin Işık Hakkındaki Yanlış Kavramları. Kastamonu Eğitim Dergisi, 4(5), 109-120.

Büyükkasap, E., Düzgün, B., Ertuğrul, M. (2001). Lise Öğrencilerinin Işık Hakkındaki Düşünceleri. IV. Fen Bilimleri Kongresi, 6-8 Eylül, Ankara.

Büyükkasap, E., Düzgün, B., Ertuğrul, M. \&Samanc1, O. (1998). Bilgisayar Destekli Fen Öğretiminin Kavram Yanılgıları Üzerine Etkisi. Kastamonu Eğitim Dergisi, 6(2), 59-66.

Cansüngü K, Ö. \& Bal, S. (2002), İlköğretim 5. ve 6. Sınıf Öğrencilerinin Iş̧ı ve Işı̆̆ın Hızı ile İlgili Yanlış Kavramları ve Bu Kavramları Oluşturma Şekilleri, G.Ü. Gazi Eğitim Fakültesi Dergisi, 22(1), 1-11.

Carmichael, P., Driver, R., Holding, B., Twigger, D. \& Watts, M. (1990). Research on Children's Conceptions in Science: a Bibliography. Leeds, UK: Children's Learning in Science Research Group, Centre for Studies in Science and Mathematics Education, University of Leeds.

Chen, C. C., Lin, H. S.\& Lin, M. L. (2002). Developing a Two-Tier Diagnostic Instrument to Assess High School Students' Understanding-the Formation of Images by a Plane Mirror. Proceedings-National Science Council Republic of China Part D Mathematics Science and Technology Education, 12(3),

Demirbaş, M., Tanrıverdi, G., Altııı̧ık, D. \& Şahintürk, Y. (2011). Fen Bilgisi Öğretmen Adaylarının Çözeltiler Konusundaki Kavram Yanılgılarının Giderilmesinde Kavramsal Değişim Metinlerinin Etkisi. Sakarya University Journal of Education, 1(2), 52-69.

Driver, R.\& Easly, J. (1978). Pupil and Paradigms: A Review of the Literature Related to Concept Development in Adolescent Science Students. Studies in Science Education, 5, 61-84.

Ery1lmaz, A. (2002). Effects of Conceptual Assingments and Conceptual Change Discussion on Students' Misconceptions and Achievement Regarding Force and Motion. Journal of Research In Science Teaching, 31(10), 1001-1015.

Esiobu, G. O. \&Soyibo, K.(1995). Effects of Concept and Vee Mapping Under Three Learning Modes on Students' Cognitive Achievement in Ecology and Genetics. Journal of Research in Science Teaching, 32, 971-995. 
Aydın, S. (2017). Eliminating the misconceptions about image formation in plane mirrors by conceptual change texts. International Journal of Social Sciences and Education Research, 3(4), 1394-1403.

Fetherstonehaugh, T. \&Treagust, D. V. (1992). Students' Understanding of Light and İts Properties: Teaching to Engender Conceptual Change. Science Education, 76(6), 653-672.

Fraenkel, J.R. \& Wallen, N.E. (2003). How to Design and Evaluate Research in Education. New York, NY: McGraw-Hill.

Geban, Ö. \& Bayır, G. (2000). Effect of Conceptual Change Approach on Students' Understanding of Chemical Change and Conservation of Matter. Hacettepe Üniversitesi Eğitim Fakültesi Dergisi, 19, 7984.

Gilbert, J. K. \& Watts, D. M. (1983). Concepts, Misconceptions and Alternative Conceptions: Changing Perspectives in Science Education. Studies in Science Education, 10, 61-90.

Griffiths, A.K. \& Preston, K. R. (1992). Grade-12 Students' Misconceptions Relating to Fundamental Characteristics of Atoms and Molecules. Journal of Research in Science Teaching, 29, 6, 611-628.

Helm, H. (1980). Misconceptions in Physics Amongst South African Students. Physics Education, 15(2), 92-97.

Hewson, P. W. \& Hewson, M. G. B. (1984). The Role of Conceptual Conflict in Conceptual Change and The Design of Science Instruction. Instructional Science, 13(1), 1-13.

Kaya A. \&Büyükkasap E. (2004). Fen Bilgisi Öğretmen Adaylarının Işık ve Atom Kavramlarını Anlama Seviyelerinin Tespiti, 6. Ulusal Fen Bilimleri ve Matematik Eğitimi Kongresi, 9-11 Eylül, Marmara Ün., İstanbul.

Kaya, F. (2010). Fen Bilgisi Öğretmen Adaylarında Fotosentez ve Bitkilerde Solunum Konularında Görülen Kavram Yanılgılarının Giderilmesinde Bilgisayar Destekli Kavramsal Değişim Metinlerinin Etkisi (Master's thesis, Pamukkale Üniversitesi Fen Bilimleri Enstitüsü).

Kaya, S. \& Kavcar, N. (2002). Ortaöğretim Fizik Dersi Mercekler Konusu Öğretim Programı Geliştirme Üzerine Bir Çalışma. V. Ulusal Fen Bilimleri ve Matematik Eğitim Kongresi 16-18 Eylül, Ankara.

Linn, R. L. \& Gronlund, N. E. (2000). Measurement and Assessment in Teaching (81hEdition). New Jersey, USA: Prentiee Hall

Novak, J. D., (1977). A Theory of Education. Ithaca, NY, Cornel University press.

Özcan, S. \&Oluk, S. (2007). İlköğretim Fen Bilgisi Derslerinde Kullanilan Sorularin Piaget ve Bloom Taksonomisine Göre Analizi. D.Ü.Ziya Gökalp Eğitim Fakültesi Dergisi 8, 61-68.

Özkan, Ö. Tekkaya \&C. Geban, Ö. (2001). Ekoloji Konularındaki Kavram Yanılgılarının Kavramsal Değişim Metinleri İle Giderilmesi. Yeni Bin Yılın Basında Fen Bilimleri Eğitimi Sempozyumu, Maltepe.

Palmer, D. H. (2003). Investigating the Relationship Between Refutational Text and Conceptual Change. Science Education, 87, 663-684.

Pfundt, H. \& Duit, R. (1991). Bibliography: Students' Alternative Frameworks and Science Education. 3rd ed. Kiel, Institute for Science Education, Univerity of Kiel.

Pınarbası, T. (2002). Çözünürlükle İlgili Kavramların Anlaşılmasında Kavramsal Değişim Yaklaşımının Etkinliğinin İncelenmesi. Yayınlanmamış Doktora Tezi, Atatürk Üniversitesi Fen Bilimleri Enstitüsü, Erzurum.

Posner, G. Strike, K. Hewson, D. Gertzog, W. (1982). "Accommodation of a Scientific Conception: Toward a Theory of Conceptual Change. Science Education, 66(2), 211-227.

Sarı Ay, Ö. \& Aydoğdu, C. (2015). Maddenin Halleri ve Isı Konusunda Kavram Yanılgılarının Giderilmesinde Kavramsal Değişim Metinlerinin Etkisi. Hacettepe Üniversitesi Ĕ̆itim Fakültesi Dergisi, 30(2), 99-111.

Üce, M. \& Sarıçayır, H. (2013). Kavramsal Değişim Metinlerinin Madde ve Özellikleri Konusunun Öğretimindeki Başarıya Etkisi. Eğitim Bilimleri Dergisi, 30(30), 159-172

Wandersee, J. H. Mintzes, J. J. Novak, J. D. (1994). Research on Alternative Conceptions in Science. In D. L. Gabel (Eds) Handbook of Research on Science Teaching and Learning, Macmillan, 177-210. 